Suherman, C. $\cdot$ M. A. Soleh $\cdot$ A. Nuraini $\cdot$ Annisa NF

\title{
Pertumbuhan dan hasil tanaman cabai (Capsicum Sp.) yang diberi pupuk hayati pada pertanaman kelapa sawit (Elaeis guineensis Jacq.) TBM I
}

\section{The growth and yield of chili crop (Capsicum sp.) under application of organic fertilizer on oil palm (Elaeis guineensis Jacq.) cultivation at $1^{\text {st }}$ Immature Plant}

Diterima : 8 Juli 2018/Disetujui : 1 Agustus 2018 / Dipublikasikan : 7 Agustus 2018

CDepartment of Crop Science, Padjadjaran University

\begin{abstract}
Intercropping system on immature plant of oil palm is an alternative cropping system to reach land optimization. In immature oil palm plantation there is $75 \%$ uncover space among the crops which could be used for cultivating annual crops. Generally, oil palm is cultivated on marginal land, so that to optimize the growth of annual crop is needed proper variety and fertilization. The objective of this research was to get the best interaction effect among variety and dosage of organic fertilizer at year 1 immature palm. The experiment was conducted at experimental station of Agricultural Faculty, Universitas Padjadjaran from Oct 2017 to Feb. 2018, it used of split plot. Variety was a main plot with two level namely: CK5 and CB2, the dosage of organic fertilizer was a sub plot with six level namely: 0, 50, 100, 150, 200, and $250 \mathrm{~mL}$ of organic fertilizer. All treatments were repeated for four times. The growth and yield of chili crop were affected independently by variety or fertilizer dosage even by interaction of both. CK5 and $200 \mathrm{~mL}$ of fertilizer showed better on plant height, canopy width, and number of branch, whereas interaction effect of CB2 and 150 $\mathrm{mL}$ of fertilizer showed the best on plant growth. Independent effect of organic fertilizer of $150 \mathrm{~mL}$ affected on plant height, canopy width, branch number, fruits number and weight of chill crop. Independent effect of variety of CK5 showed better than of CB2 on plant height, fruit number and yield.
\end{abstract}

Keywords : Intercropping - Chili variety • Organic fertilizer

Sari. Penerapan sistem tanam tumpangsari pada tanaman belum menghasilkan (TBM) kelapa sawit

\footnotetext{
Dikomunikasikan oleh Memet Hakim

C. Suherman ${ }^{1} \cdot$ M.A. Soleh ${ }^{1} \cdot$ A. Nuraini ${ }^{1} \cdot$ Annisa NF1 .

Departemen Budidaya Pertanian Fakultas Pertanian UNPAD

Korespondensi: cucu.suherman@unpad.ac.id
}

merupakan upaya optimalisasi lahan. Pada TBM I terdapat $75 \%$ ruang terbuka yang dapat ditanami tanaman sela, misalnya tanaman cabai. Tanaman sawit umumnya ditanam pada lahan marginal, maka untuk optimasi pertumbuhan tanaman sela perlu dipilih varietas yang baik dan dilakukan pemupukan. Penelitian bertujuan untuk memperoleh pengaruh interaksi terbaik varietas dan dosis pupuk hayati terhadap pertumbuhan dan hasil tanaman cabai yang ditanam pada pertanaman kelapa sawit TBM 1. Percobaan dilakukan mulai Oktober 2017 sampai Pebruari 2018 di Kebun Percobaan Fakultas Pertanian, Universitas Padjadjaran. Ordo tanah inceptisol. Tipe curah hujan C menurut klasifikasi Schmidt dan Ferguson, ketinggian tempat $\pm 780 \mathrm{mdpl}$. Rancangan menggunakan Split plot design, varietas sebagai main plot terdiri atas dua taraf, yaitu CK5 dan CB2 dan dosis pupuk hayati sebagai sub plot terdiri atas enam taraf, yaitu 0, 50, 100, 150, 200 dan $250 \mathrm{~mL} /$ tanaman. Setiap perlakuan diulang empat kali. Hasil penelitian menunjukkan Pertumbuhan dan hasil tanaman cabai dipengaruhi secara mandiri maupun interaksi varietas dan dosis pupuk hayati. Pada CK5 taraf dosis pupuk hayati $200 \mathrm{~mL} /$ tanaman menghasilkan tinggi tanaman, lebar kanopi dan jumlah cabang yang lebih baik. Pada CB2, taraf dosis $150 \mathrm{~mL} /$ tanaman memberikan pengaruh interaksi lebih baik. Secara mandiri, dosis pupuk hayati $150 \mathrm{~mL} /$ tanaman menghasilkan pertumbuhan terbaik pada tinggi tanaman, lebar kanopi, jumlah cabang, bobot dan jumlah buah tanaman cabai, sementara untuk varietas CK5 menghasilkan tinggi tanaman, jumlah cabang, panjang dan jumlah buah yang lebih baik dibanding CB2.

Kata kunci : Tumpangsari • Varietas cabai • Pupuk hayati. 


\section{Pendahuluan}

Kelapa sawit (Elaeis guineensis) merupakan salah satu komoditas perkebunan yang mempunyai peran cukup penting dalam kegiatan perekonomian Indonesia. Selain sebagai salah satu penghasil devisa Negara, kelapa sawit juga menyerap banyak tenaga kerja bagi masyarakat Indonesia (Indarti, 2014). Sehingga luas arealnya terus bertambah,

Pada tahun 2015 luas areal tanaman kelapa sawit di Indonesia adalah 11.300.370 Ha dengan peruntukan 22,2\% areal Tanaman Belum Menghasilkan (TBM), 75,3\% areal Tanaman Menghasilkan (TM), dan 2,5\% areal tanaman rusak (TR), dan pada tahun 2016 luas total bertambah menjadi 11.672.861 $\mathrm{Ha}$ dengan peruntukan $22,74 \%$ areal TBM, $75,2 \%$ areal TM dan 2,06\% areal TR. (Direktorat Jenderal Perkebunan, 2015).

Data tersebut menunjukkan proporsi luasan kelapa sawit pada masa TBM cukup besar setiap tahunnya yaitu sekitar 22-23\%. TBM sawit biasanya berlangsung 30-36 bulan. Mengingat jarak tanam yang cukup lebar $(9 \times 9$ m) dan kanopi sawit yang masih kecil, maka selama TBM ada potensi ruang terbuka mencapai $75 \%$ pada TBM 1 dan $60 \%$ pada TBM 2 (Wasito, 2013). Ruang terbuka tersebut kalau tidak dikelola, maka akan ditumbuhi gulma yang berpotensi merugikan terhadap tanaman sawit. Oleh sebab itu, ruang terbuka tersebut biasanya ditanami tanaman penutup tanah yang berfungsi untuk menekan pertumbuhan gulma, selain itu agar penutup tanah juga dapat menyumbang peningkatan kesuburan tanah, maka dipilih tanaman dari kelompok legume (Legume Cover Crop/LCC).

Ruang terbuka antar kelapa sawit pada TBM, selain ditanami LCC, dapat juga ditanami tanaman sela, sehingga dalam areal yang sama ditanami lebih dari satu jenis tanaman, pola tanam ini dikenal dengan istilah tumpangsari. Tanaman sela digunakan sebagai pengganti tanaman penutup tanah (Manurung dkk., 2015) dan dapat memberikan nilai tambah yang menguntungkan (Armaini dkk., 2012). Adanya tanaman sela pada pola tanam tumpangsari dapat menjadi sumber penghasilan selama tanaman kelapa sawit belum menghasilkan pendapatan. Menurut Balai Besar Pengkajian dan Pengembangan Teknologi Pertanian (2008) tanaman sela yang dapat digunakan pada areal lahan kelapa sawit adalah ubi kayu, jagung, padi, dan tanaman lainnya. Salah satu tanaman yang dapat ditanam di bawah tegakan sawit TBM I adalah tanaman cabai yang memiliki sistem perakaran dangkal.

Cabai merupakan salah satu komoditas pertanian yang penting dan banyak dibudidayakan di Indonesia. Cabai memiliki aroma, rasa dan warna yang spesifik, sehingga banyak digunakan oleh masyarakat sebagai rempah dan bumbu masakan. Seiring dengan bertambahnya penduduk, kebutuhan cabai di Indonesia pun semakin meningkat (Soelaiman dan Ernawati, 2013).

Seiring dengan permintaan cabai yang terus meningkat, penanaman cabai pada tegakan sawit belum menghasilkan merupakan salah satu alternatif yang dapat digunakan untuk memenuhi permintaan, juga sebagai sarana optimalisasi lahan. Terkait dengan pemanfaatan lahan tersebut, permasalahan yang umum dihadapi pada perkebunan sawit adalah rendahnya kesuburan tanah, baik fisik, kimia maupun biologi, sehingga agar penanaman tanaman sela menghasilkan manfaat yang optimal, maka perlu dilakukan perbaikan kesuburan tanah, antara lain melalui pemupukan, diantaranya dengan pemberian pupuk hayati.

Berbeda dengan pupuk organik, pupuk hayati merupakan suatu produk berbahan aktif organisme hidup yang berfungsi sebagai penambat hara tertentu sehingga tersedia bagi tanaman. Peningkatan penyediaan hara dapat berlangsung dikarenakan adanya cendawan ataupun mikroba yang bersimbiosis atau nonsimbiosis dengan tanaman (Simanungkalit dkk., 2006). Istilah pupuk hayati digunakan sebagai nama kolektif untuk semua mikroba tanah yang dapat membantu menyediakan hara dalam tanah, sehingga hara tersebut tersedia bagi tanaman (Rosliani dkk., 2004).

Selain pupuk hayati faktor lain yang dapat meningkatkan produksi tanaman cabai adalah penggunaan bahan tanam yang baik. Menurut Hayati dkk. (2012), bahan tanam akan berkaitan dengan faktor internal dimana perangsang pertum-buhan tanaman dikendalikan oleh faktor genetik, sementara unsur eksternal seperti iklim, tanah dan biologi seperti hama, penyakit, gulma, serta pesaing hara akan mempengaruhi pertumbuhan dan hasilnya. Di antara varietas cabai unggul yang dikembangkan oleh Fakultas Pertanian Universitas Padjadjaran adalah CK5 dan CB2. 
Penelitian ini bertujuan untuk memperoleh pengaruh interaksi terbaik dosis pupuk hayati dan jenis varietas cabai terhadap pertumbuhan dan hasil tanaman cabai yang ditanam pada pertanaman kelapa sawit TBM I.

\section{Bahan dan Metode}

Percobaan ini dilaksanakan di Kebun Percobaan Ciparanje, Fakultas Pertanian, Universitas Padjadjaran, Jatinangor, ketinggian tempat \pm 780 $\mathrm{m}$ dpl. Ordo tanah Inceptisols. Tipe iklim C menurut klasifikasi Schmidt dan Ferguson (1951). Percobaan dimulai pada bulan November 2017 sampai dengan bulan Februari 2018.

Bahan tanam yang digunakan adalah tanaman cabai varietas CK5 dan CB2 dan tanaman kelapa sawit varietas SEU supreme mekarsari TBM I. Bahan lainnya yaitu pupuk kompos, pupuk anorganik, dan pupuk hayati Bion Up. Alat yang digunakan timbangan analitik, meteran, dan kamera.

Rancangan yang digunakan adalah rancangan petak terbagi atau split plot design dengan varietas sebagai main plot dan dosis pemupukan sebagai sub plot.

Main Plot: varietas cabai terdiri dari dua taraf yaitu : CK5 dan CB2

Sub Plot: adalah dosis pupuk hayati (b) terdiri atas enam taraf yaitu:

b0 : tanpa pemberian pupuk hayati

b1 : pemberian dosis pupuk hayati 50

$\mathrm{mL} /$ tanaman

b2 : pemberian dosis pupuk hayati 100

$\mathrm{mL} /$ tanaman

b3 : pemberian dosis pupuk hayati 150

$\mathrm{mL} /$ tanaman

b4 : pemberian dosis pupuk hayati 200

$\mathrm{mL} /$ tanaman

b5 : pemberian dosis pupuk hayati 250

$\mathrm{mL} /$ tanaman

Penggunaan konsentrasi disesuaikan dengan rekomendasi produsen, yaitu konsentrasi 10ml/liter air. Seluruh pengaruh dari setiap perlakuan dianalisis melalui analisis ragam dengan uji $\mathrm{F}$ pada taraf kepercayaan 95\%. Bila uji $\mathrm{F}$ berbeda nyata, selanjutnya dilakukan uji Tukey pada taraf $5 \%$.

Jarak tanam kelapa sawit $8 \mathrm{~m} \times 8 \mathrm{~m}$, jarak antara kelapa sawit dengan cabai $2 \mathrm{~m}$ dan jarak tanam cabai $50 \mathrm{~cm} \times 50 \mathrm{~cm}$. Bedengan cabai ditutup dengan mulsa plastic hitam perak. Bibit cabai yang ditanam adalah hasil semai berumur satu bulan dan telah memiliki 4-5 daun. Penanaman dilakukan dengan system double row.

Pemeliharaan untuk tanaman cabai meliputi pemasangan ajir, perempelan, penyiraman, pemupukan, penyiangan, dan pengendalian hama dan penyakit, sementara untuk tanaman kelapa sawit meliputi penyiangan, pemupukan, dan penyiraman. Penyiraman dilakukan setiap hari pada pagi atau sore hari. Pupuk dasar untuk tanaman cabai $0,5 \mathrm{~kg}$ pupuk kandang per tanaman. Pupuk susulan diberikan berupa NPK $(15: 15: 15)$ dengan dosis $200 \mathrm{~kg} / \mathrm{ha}$ yang diberikan pada umur 3, 6, dan 9 minggu setelah tanam. Pemupukan untuk tanaman kelapa sawit umur satu tahun adalah dengan pengaplikasian pupuk NPK (15:15:15) sebanyak $200 \mathrm{~g} /$ tanaman. Penyiangan gulma dilakukan dua minggu sekali, sedangkan pengendalian hama dan penyakit dilakukan hanya apabila diperlukan.

Pupuk hayati diaplikasikan sesuai konsentrasi dan dosis sesuai perlakuan. Aplikasi pupuk hayati dilakukan pada 7 hari setelah tanam (HST), 14 HST dan 21 HST, diaplikasikan langsung ke tanah di sekitar tanaman.

Pemanenan cabai dilakukan saat buah cabai menunjukkan matang panen, yaitu saat umur tanaman berumur 80-90 hari setelah tanam. Pemanenan dilakukan pagi hari dengan cara dipetik dengan tangkai buahnya agar buah tidak mengalami busuk dan dimasukan ke dalam kantong plastik. Pemanenan dilakukan sebanyak 3 kali. Menurut Sudarmi dkk (2013) pemanenan yang menguntungkan secara ekonomis hanya sampai 3 kali panen.

Pengamatan dilakukan terhadap tinggi tanaman, jumlah cabang, lebar kanopi, bobot buah dan panjang buah.

Tinggi tanaman $(\mathrm{cm})$, Jumlah cabang, dan Lebar kanopi (cm), diukur mulai umur 2 Minggu Setelah Tanam (MST), 4 MST, 6 MST, 10 MST, dan 12 MST. Sedangkan Bobot buah segar (g), dihitung dengan menjumlahkan bobot cabai hasil tiga kali panen. Panjang buah (cm), diukur panjangnya dari ujung tangkai sampai dengan pangkal buah, dirata ratakan dari tiga sampel per perlakuan. Jumlah buah dihitung dengan menjumlahkan buah hasil tiga kali panen.

\section{Hasil dan Pembahasan}

Tinggi tanaman cabai. Hasil analisis data menunjukkan terdapat pengaruh interaksi varietas dan dosis pupuk hayati terhadap tinggi tanaman 
cabai pada umur 10 MST yang ditanam di bawah tegakan sawit TBM I (Tabel 1). Data menunjukkan bahwa, variasi dosis pupuk hayati pada varietas CK5 tidak menghasilkan pengaruh yang berbeda nyata, tetapi pada varietas CB3, tinggi tanaman dipengaruhi secara nyata oleh dosis pupuk hayati. Pada vaietas CB3, dosis pupuk hayati 150 $\mathrm{mL} /$ tanaman (dosis rekomendasi produsen) menghasilkan pengaruh interaksi paling baik terhadap tinggi tanaman cabai.

Hasil analisis pengruh mandiri menunjukkan bahwa pada 6 dan 8 MST varietas CK5 memberikan tinggi tanaman lebih baik dibandingkan dengan varietas CB2. Sedangkan pengaruh mandiri dosis yang lebih baik pada umur 6, 8, dan 12 MST ditunjukkan pada pemberian dosis $150 \mathrm{~mL} /$ tanaman (Tabel 2).

Pupuk hayati dapat berperan meningkatkan tinggi tanaman, karena pupuk tersebut mengandung mikroorganisme yang mampu mengikat nitrogen dari udara, melarutkan fosfat yang terikat di dalam tanah, dan mampu memecah senyawa organik kompleks menjadi senyawa yang sederhana sehingga dapat memacu pertumbuhan tanaman (Suswahyono 2011). Bakteri penambat nitrogen akan membantu mengubah $\mathrm{N}_{2}$ dari udara menjadi $\mathrm{NH}_{3}$ dengan menggunakan enzim nitrogenase, kemudian $\mathrm{NH}_{3}$ diubah menjadi glutamin dan alanin sehingga dapat diserap oleh tanaman, sedangkan bakteri pelarut fosfat berfungsi menghidrolisis $\mathrm{P}$ organik menjadi fosfat anorganik yaitu $\mathrm{H}_{2} \mathrm{PO}_{4}^{-}$dan $\mathrm{HPO}_{4}^{-}$yang menjadi tersedia bagi tanaman (Widawati, 2015).

Menurut Permatasari dan Nurhidayati (2014) Unsur hara mikro dan makro mempunyai peranan penting dalam mendukung pertumbuhan dan produksi tanaman. Unsur $\mathrm{N}$ dan $\mathrm{Fe}$ sangat dibutuhkan tanaman dalam proses pembentukkan klorofil dan sintesis protein yang dikandung dalam kloroplas, serta merangsang pertumbuhan vegetatif tanaman. Tersedianya unsur $\mathrm{N}$ pada tanaman yang disebabkan oleh mikroorganisme akan meningkatkan kandungan

Tabel 1. Pengaruh interaksi varietas dan dosis pupuk hayati terhadap tinggi tanaman cabai pada 10 MST di bawah tegakan kelapa sawit TBM I.

\begin{tabular}{lcccccc}
\hline \multirow{2}{*}{ Varietas } & \multicolumn{6}{c}{ Dosis Pupuk Hayati } \\
\cline { 2 - 7 } & $\mathrm{b} 0$ & $\mathrm{~b} 1$ & $\mathrm{~b} 2$ & $\mathrm{~b} 3$ & $\mathrm{~b} 4$ & $\mathrm{~b} 5$ \\
\hline CK5 & $45,06 \mathrm{a}$ & $46,60 \mathrm{a}$ & $43,40 \mathrm{~b}$ & $52,57 \mathrm{a}$ & $51,50 \mathrm{a}$ & $44,91 \mathrm{a}$ \\
& $\mathrm{A}$ & $\mathrm{A}$ & $\mathrm{A}$ & $\mathrm{A}$ & $\mathrm{A}$ & $\mathrm{A}$ \\
CB2 & $39,63 \mathrm{a}$ & $44,88 \mathrm{a}$ & $51,55 \mathrm{a}$ & $56,16 \mathrm{a}$ & $48,22 \mathrm{a}$ & $43,17 \mathrm{a}$ \\
& $\mathrm{C}$ & $\mathrm{BC}$ & $\mathrm{AB}$ & $\mathrm{A}$ & $\mathrm{ABC}$ & $\mathrm{BC}$ \\
\hline
\end{tabular}

Keterangan : Data yang diikuti huruf kecil yang sama arah vertikal dan data yang diikuti huruf besar yang sama arah horizontal menunjukkan tidak berbeda nyata menurut Tukey pada taraf kepercayaan $95 \%$.

Tabel 2. Pengaruh mandiri varietas dan dosis pupuk hayati terhadap tinggi tanaman cabai di bawah tegakan kelapa sawit TBM I.

\begin{tabular}{cccccc}
\hline \multirow{2}{*}{ Perlakuan } & \multicolumn{5}{c}{ Rata-rata Tinggi tanaman $(\mathrm{cm})$} \\
\cline { 2 - 6 } & $2 \mathrm{MST}$ & 4 MST & $6 \mathrm{MST}$ & $8 \mathrm{MST}$ & $12 \mathrm{MST}$ \\
\hline Vaeritas Cabai & 17,76 & 19,01 & $24,75 \mathrm{~b}$ & $36,91 \mathrm{~b}$ & 52,13 \\
CK5 & 18,08 & 19,58 & $26,82 \mathrm{a}$ & $40,09 \mathrm{a}$ & 50,83 \\
CB2 & & & & & \\
Dosis Pupuk Hayati & 19,22 & 19,96 & $24,34 \mathrm{bc}$ & $33,87 \mathrm{c}$ & $47,61 \mathrm{~b}$ \\
b0 & 15,94 & 17,46 & $22,96 \mathrm{c}$ & $36,88 \mathrm{bc}$ & $48,78 \mathrm{~b}$ \\
b1 & 17,11 & 18,45 & $23,49 \mathrm{c}$ & $38,51 \mathrm{bc}$ & $52,04 \mathrm{ab}$ \\
b2 & 19,16 & 20,51 & $29,34 \mathrm{a}$ & $46,11 \mathrm{a}$ & $57,55 \mathrm{a}$ \\
b3 & 18,5 & 20,43 & $28,83 \mathrm{ab}$ & $39,77 \mathrm{~b}$ & $51,54 \mathrm{ab}$ \\
b4 & 17,61 & 18,94 & $25,75 \mathrm{abc}$ & $35,86 \mathrm{bc}$ & $50,33 \mathrm{~b}$ \\
b5 &
\end{tabular}

Keterangan : Nilai rata-rata yang diikuti huruf yang sama pada kolom yang sama tidak berbeda nyata menurut Tukey pada taraf kepercayaan $95 \%$. 
ngan klorofil pada daun sehingga proses fotosintesis juga meningkat, serta asimilat yang dihasilkan lebih banyak yang menyebabkan pertumbuhan tanaman lebih baik, Selain itu menurut Liferdi (2010) unsur P yang tersedia bagi tanaman membantu dalam pembentukkan sel baru pada jaringan yang sedang tumbuh, sehingga dapat meningkatkan pertumbuhan tanaman.

Lebar kanopi. Hasil analisis ragam menunjukkan terdapat pengaruh interaksi antara varietas dan dosis pupuk hayati terhadap lebar kanopi pada 12 MST (Tabel 3), sedangkan secara mandiri varietas cabai tidak berpengaruh nyata terhadap lebar kanopi, namun penambahan pupuk hayati dapat berpengaruh nyata terhadap lebar kanopi tanaman cabai pada 8 dan 10 MST (Tabel 4).

Data interaksi yang disajikan pada Tabel 3 menunjukkan bahwa pada CB2, pemberian dosis pupuk hayati $150 \mathrm{~mL} /$ tanaman menghasilkan pertumbuhan lebar kanopi yang paling lebar, sedangkan untuk varietas CK5 dosis terbaik terlihat pada dosis $150 \mathrm{ml} /$ tanaman dan
$200 \mathrm{~mL} /$ tanaman, walaupun hanya berbeda dengan control (tanpa perlakuan puuk hayati). Secara mandiri lebar kanopi hanya dipengaruhi oleh dosis pupuk hayati. Pemberian dosis pupuk $150 \mathrm{~mL} /$ tanaman menghasilkan lebar kanopi terbaik bagi tanaman cabai varietas CK5 maupun CB2 (Tabel 4).

Pupuk hayati mengandung berbagai mikroorganisme yang dapat meningkatkan ketersediaan unsur hara bagi tanaman, salah satunya adalah bakteri pelarut fosfat. Menurut Elfiati (2005) beberapa bakteri pelarut fosfat tidak hanya mampu meningkatkan ketersediaan unsur $\mathrm{P}$ bagi tanaman tetapi juga dapat menghasilkan berbagai macam zat pengatur tumbuh seperti asam indol asetat (IAA) dan giberalin (GA3) yang dapat berpengaruh terhapat pertumbuhan tanaman. Hasil penelitian Anjarsari dkk. (2015) menunjukkan kombinasi 1,0 g PHK/ tanaman $+10 \mathrm{~mL}$ Asam humat menghasilkan kecenderungan nilai laju asimilasi bersih, luas daun, nisbah luas daun yang lebih tinggi dibandingkan perlakuan lainnya.

Tabel 3. Pengaruh interaksi varietas dan dosis pupuk hayati terhadap lebar kanopi tanaman cabai pada 12 MST yang ditanam pada tegakan tanaman sawit TBM I.

\begin{tabular}{|c|c|c|c|c|c|c|}
\hline \multirow{2}{*}{ Varietas } & \multicolumn{6}{|c|}{ Dosis Pupuk Hayati } \\
\hline & b0 & b1 & b2 & b3 & $\mathrm{b} 4$ & b5 \\
\hline & \multicolumn{6}{|c|}{ - } \\
\hline CK5 & $\begin{array}{c}42,77 \mathrm{a} \\
\text { B }\end{array}$ & $\begin{array}{c}44,96 \text { a } \\
\text { AB }\end{array}$ & $\begin{array}{c}44,6 \text { a } \\
A B\end{array}$ & $\begin{array}{c}54,01 \mathrm{a} \\
\mathrm{A}\end{array}$ & $\begin{array}{c}53,85 \text { a } \\
\text { A }\end{array}$ & $\begin{array}{c}51,45 \mathrm{a} \\
\mathrm{AB}\end{array}$ \\
\hline CB2 & $\begin{array}{c}40,73 a \\
\text { B }\end{array}$ & $\begin{array}{c}47,29 a \\
A B\end{array}$ & $\begin{array}{c}48,21 \mathrm{a} \\
\mathrm{AB}\end{array}$ & $\begin{array}{c}52,29 a \\
\text { A }\end{array}$ & $\begin{array}{c}44,75 \mathrm{~b} \\
\mathrm{AB}\end{array}$ & $\begin{array}{c}40,46 \mathrm{~b} \\
\text { B }\end{array}$ \\
\hline
\end{tabular}

Keterangan : Data yang diikuti huruf kecil yang sama arah vertikal dan data yang diikuti huruf besar yang sama arah horizontal menunjukkan tidak berbeda nyata menurut uji Tukey pada taraf kepercayaan $95 \%$.

Tabel 4. Pengaruh mandiri varietas dan dosis pupuk hayati terhadap lebar kanopi tanaman cabai yang ditanam pada tegakan tanaman sawit TBM I.

\begin{tabular}{cccccc}
\hline \multirow{2}{*}{ Perlakuan } & \multicolumn{5}{c}{ Rata-rata Lebar Kanopi (cm) } \\
\cline { 2 - 6 } & 2 MST & 4 MST & 6 MST & 8 MST & 10 MST \\
\hline Vaeritas Cabai & 12,26 & 13,31 & 15,95 & 25,53 & 41,32 \\
CK5 & 11,68 & 13,18 & 15,81 & 28,2 & 40,06 \\
CB2 & & & & & \\
Dosis Pupuk Hayati & 12,09 & 13,03 & 14,79 & $24,94 \mathrm{~b}$ & $36,83 \mathrm{~b}$ \\
b0 & 11,22 & 12,68 & 14,8 & $24,69 \mathrm{~b}$ & $39,22 \mathrm{~b}$ \\
b1 & 12,13 & 13,6 & 15,13 & $28,39 \mathrm{ab}$ & $42,21 \mathrm{ab}$ \\
b2 & 12,34 & 13,63 & 17,38 & $32,09 \mathrm{a}$ & $47,54 \mathrm{a}$ \\
b3 & 12,09 & 13,18 & 16,76 & $28,23 \mathrm{ab}$ & $39,39 \mathrm{ab}$ \\
b4 & 11,94 & 13,35 & 16,42 & $26,22 \mathrm{~b}$ & $37,86 \mathrm{~b}$ \\
b5 & &
\end{tabular}

Keterangan : Nilai rata-rata yang diikuti huruf yang sama pada kolom yang sama tidak berbeda nyata menurut uji Tukey pada taraf kepercayaan 95\%. 
Interaksi antara varietas dan dosis pupuk hayati pada tanaman cabai di bawah tegakan sawit (Tabel 3) menunjukkan bahwa pada 12 MST dosis pupuk hayati yang lebih kecil maupun lebih besar dari dosis rekomendasi cenderung menurunkan lebar kanopi. Menurut Hayati dkk. (2012) setiap varietas memiliki respons genotipe yang berbeda pada berbagai lingkungan tumbuh, hal tersebut akan berpengaruh terhadap penampilan fenotip tiap varietas apabila terjadi interaksi dengan lingkungan tumbuhnya.

Jumlah cabang. Data dan hasil analisis statistik pengaruh varietas dan jumlah dosis pupuk hayati terhadap jumlah cabang menunjukkan bahwa, terdapat pengaruh interaksi antara jenis varietas dan dosis pupuk hayati terhadap jumlah cabang pada 12 MST (Tabel 5).

Data juga menunjukkan adanya pengaruh interaksi (Tabel 5) dan pengaruh mandiri dosis pupuk hayati terhadap jumlah cabang tanaman cabai (Tabel 6). Pengaruh interaksi antara varietas dan dosis terlihat pada perlakuan 12 MST yang menunjukkan varietas CB2 maupun
CK5, jumlah cabangnya dipengaruhi oleh dosis pupuk hayati.

Dosis yang baik untuk meningkatkan jumlah cabang berbeda antara kedua varietasnya. Varietas CK5 menunjukkan bahwa dengan dosis $200 \mathrm{~mL} /$ tanaman menghasilkan pertumbuhan jumlah cabang yang paling baik, namun pada varietas CB2 dosis terbaik yang dapat meningkatkan jumlah cabang pada tanaman cabai adalah $150 \mathrm{~mL} /$ tanaman.

Hasil analisis mandiri menunjukkan bahwa tidak terdapat pengaruh nyata perlakuan varietas terhadap jumlah cabang, namun perlakuan dosis menghasilkan pengaruh yang berbeda nyata. Pada umur 6 MST, 8 MST dan 10 MST menunjukkan bahwa dosis 150 $\mathrm{mL} /$ tanaman memberikan jumlah cabang terbaik bagi tanaman cabai.

Menurut Ariesna dkk. (2014) Setiap varietas memiliki kemampuan berbeda antara satu varietas dengan varietas lainnya, setiap varietas membahwa bahan genetiknya sendiri. Menurut Harahap (2012) setiap gen bertanggung jawab terhadap sintesis protein, enzim, dan hormon dari varietas itu sendiri.

Tabel 5. Pengaruh interaksi varietas dan dosis pupuk hayati terhadap jumlah cabang tanaman cabai pada 12 MST yang ditanam pada tegakan sawit TBM I.

\begin{tabular}{lcccccc}
\hline \multirow{2}{*}{ Varietas } & \multicolumn{7}{c}{ Dosis Pupuk Hayati } \\
\cline { 2 - 7 } & $\mathrm{b} 0$ & $\mathrm{~b} 1$ & $\mathrm{~b} 2$ & $\mathrm{~b} 3$ & $\mathrm{~b} 4$ & $\mathrm{~b} 5$ \\
\hline CK5 & $24 \mathrm{a}$ & $26,5 \mathrm{a}$ & $26,75 \mathrm{a}$ & $32 \mathrm{a}$ & $36,75 \mathrm{a}$ & $32,25 \mathrm{a}$ \\
& $\mathrm{C}$ & $\mathrm{BC}$ & $\mathrm{BC}$ & $\mathrm{AB}$ & $\mathrm{A}$ & $\mathrm{AB}$ \\
CB2 & $20 \mathrm{a}$ & $25,25 \mathrm{a}$ & $30,50 \mathrm{a}$ & $33,5 \mathrm{a}$ & $24 \mathrm{~b}$ & $24,25 \mathrm{~b}$ \\
& $\mathrm{C}$ & $\mathrm{BC}$ & $\mathrm{AB}$ & $\mathrm{A}$ & $\mathrm{BC}$ & BC \\
\hline
\end{tabular}

Keterangan : Data yang diikuti huruf kecil yang sama arah vertikal dan data yang diikuti huruf besar yang sama arah horizontal menunjukkan tidak berbeda nyata menurut Tukey pada taraf kepercayaan $95 \%$.

Tabel 6. Pengaruh mandiri varietas dan dosis pupuk hayati terhadap jumlah cabang tanaman cabai yang ditanam pada tegakan sawit TBM I.

\begin{tabular}{cccc}
\hline \multirow{2}{*}{ Perlakuan } & \multicolumn{3}{c}{ Rata-rata Jumlah Cabang Cabai } \\
\cline { 2 - 4 } & 6 MST & $8 \mathrm{MST}$ & $10 \mathrm{MST}$ \\
\hline Vaeritas Cabai & 4,54 & 8,58 & 19,21 \\
CK5 & 5,33 & 8,88 & 18,00 \\
CB2 & & & \\
Dosis Pupuk Hayati & $3,50 \mathrm{c}$ & $6,38 \mathrm{c}$ & $11,00 \mathrm{~d}$ \\
b0 & $3,88 \mathrm{c}$ & $7,62 \mathrm{bc}$ & $16,88 \mathrm{c}$ \\
b1 & $4,38 \mathrm{bc}$ & $9,12 \mathrm{ab}$ & $17,88 \mathrm{bc}$ \\
b2 & $6,50 \mathrm{a}$ & $10,25 \mathrm{a}$ & $24,62 \mathrm{a}$ \\
b3 & $6,00 \mathrm{ab}$ & $9,75 \mathrm{ab}$ & $21,75 \mathrm{ab}$ \\
b4 & $5,38 \mathrm{ab}$ & $9,25 \mathrm{ab}$ & $19,50 \mathrm{bc}$ \\
b5 & &
\end{tabular}

Keterangan : Nilai rata-rata yang diikuti huruf yang sama pada kolom yang sama tidak berbeda nyata menurut Tukey pada taraf kepercayaan $95 \%$. 
Bobot buah, panjang buah, dan Jumlah buah. Hasil analisis lanjut pengaruh varietas dan jumlah dosis pupuk hayati terhadap bobot buah, panjang buah, dan jumlah buah disajikan pada Tabel 7 . Data menunjukkan bahwa tidak terdapat pengaruh interaksi varietas dan dosis pupuk hayati terhadap parameter bobot buah, panjang buah dan jumlah buah. Secara mandiri, CK5 dan CB2 menghasilkan bobot buah yang sama, sedangkan dosis pupuk hayati menghasilkan bobot buah yang berbeda nyata. Perlakuan $b_{3}$ (dosis $150 \mathrm{~mL} /$ tanaman) menghasilkan bobot buah yang lebih besar dibandingkan perlakuan $b_{0}$, $b_{1}$, dan $b_{5}$ namun tidak berbeda nyata dengan perlakuan $b_{2}$ dan $b_{4}$.

Panjang buah tidak dipengaruhi secara nyata oleh dosis pupuk hayati, tetapi varietas memberikan panjang buah yang berbeda. varietas CK5 memiliki panjang buah yang lebih panjang dibandingkan dengan CB2. Sedangkan jumlah buah, secara mandiri dipengaruhi oleh varietas maupun dosis pupuk hayati.

Data hasil analisis terhadap parameter jumlah buah menunjukkan bahwa varietas CK5 memiliki jumlah buah yang lebih baik dibandingkan dengan varietas CB2. Sedangkan dosis pupuk hayati yang berpengaruh paling baik terhadap jumlah buah adalah perlakuan b3 (150 mL/tanaman). (Tabel 7). Pembentukan buah dipengaruhi oleh unsur hara N, P, dan K. Pembentukan dan pengisisan buah sangat dipengaruhi oleh unsur hara yang digunakan dalam proses fotosintesis yaitu sebagai penyusun karbohidrat, lemak, protein, mineral dan vitamin yang akan ditranslokasikan ke bagian penyimpanan buah. Mikroorganisme yang terkandung dalam pupuk hayati membantu menyediakan unsur hara sehingga dapat tersedia bagi tanaman (Wardhani dkk., 2014).
Pada parameter berat buah terlihat bahwa perlakuan $b_{5}$ atau dosis $250 \mathrm{~mL} /$ tanaman merupakan perlakuan dosis yang paling banyak namun menghasilkan berat buah yang terkecil diantara dosis lainnya. Hal tersebut diduga terjadi karena dosis pupuk hayati terlalu banyak. Menurut Wardhani dkk. (2014) aplikasi pupuk hayati yang terlalu banyak, menyebabkan kandungan mikroorganisme di dalam tanah terlalu banyak. Banyaknya populasi mikroorganisme tersebut menyebabkan terjadi-nya kompetisi antar mikroorganisme dalam mendapatkan kecukupan kebutuhan makanan, oksigen, dan air. Kurangnya kebutuhan tersebut bagi mikroorganisme menyebabkan organisme tersebut mudah mati.

\section{Kesimpulan}

Berdasarkan hasil dan pembahasan dapat diambil kesimpulan sebagai berikut :

1. Terdapat pengaruh interaksi maupun mandiri varietas dan dosis pupuk hayati terhadap pertumbuhan dan hasil tanaman cabai pada pertanaman kelapa sawit TBM I.

2. Pada taraf CK5, taraf dosis pupuk hayati 200 $\mathrm{mL} /$ tanaman menghasilkan tinggi tanaman, lebar kanopi dan jumlah cabang yang lebih baik. Pada CB2, taraf dosis $150 \mathrm{~mL} /$ tanaman memberikan pengaruh interaksi lebih baik. Secara mandiri, dosis pupuk hayati 150 $\mathrm{mL} /$ tanaman menghasilkan pertumbuhan terbaik pada tinggi tanaman, lebar kanopi, jumlah cabang, berat buah, dan jumlah buah tanaman cabai, sementara untuk varietas CK5 menghasilkan tinggi tanaman, jumlah cabang, panjang buah, dan jumlah buah yang lebih baik dibanding CB2.

Tabel 7. Pengaruh mandiri varietas dan dosis pupuk hayati terhadap rata-rata bobot buah, panjang buah, dan jumlah buah cabai pada pertanaman sawit TBM I.

\begin{tabular}{lccc}
\hline Perlakuan & Rata-rata bobot buah $(\mathrm{g})$ & Rata-rata panjang buah $(\mathrm{cm})$ & Rata-rata jumlah buah \\
\hline Vaeritas Cabai & & & \\
$\mathrm{v}_{1}=$ CK5 & $115,81 \mathrm{a}$ & $17,05 \mathrm{a}$ & $25,03 \mathrm{a}$ \\
$\mathrm{V}_{2}=$ CB2 & $113,95 \mathrm{a}$ & $12,3 \mathrm{~b}$ & $15,76 \mathrm{~b}$ \\
\hline Dosis Pupuk Hayati & & & \\
$\mathrm{b}_{0}$ & $88,32 \mathrm{c}$ & $14,53 \mathrm{a}$ & $16,23 \mathrm{~b}$ \\
$\mathrm{~b}_{1}$ & $103,55 \mathrm{bc}$ & $14,21 \mathrm{a}$ & $23,18 \mathrm{ab}$ \\
$\mathrm{b}_{2}$ & $134,59 \mathrm{ab}$ & $14,8 \mathrm{a}$ & $18,42 \mathrm{ab}$ \\
$\mathrm{b}_{3}$ & $148,05 \mathrm{a}$ & $14,8 \mathrm{a}$ & $26,16 \mathrm{a}$ \\
$\mathrm{b}_{4}$ & $114,48 \mathrm{abc}$ & $14,93 \mathrm{a}$ & $19,31 \mathrm{ab}$ \\
$\mathrm{b}_{5}$ & $100,28 \mathrm{bc}$ & $14,87 \mathrm{a}$ & $19,08 \mathrm{ab}$ \\
\hline
\end{tabular}

Keterangan : Nilai rata-rata yang diikuti huruf yang sama pada kolom dan perlakuan yang sama tidak berbeda nyata menurut Tukey pada taraf kepercayaan $95 \%$. 


\section{Daftar Pustaka}

Ariesna, F.D., Sudiarso., Herlina, N. 2014. Respon 3 varietas tanaman krisan (Chrysanthemum morifolium) pada berbagai warna cahaya tambahan. Jurnal Produksi Tanaman. Vol. 2(5) : 419-426

Armaini., Ariani, E., Yoseva, S., Anom, E. 2012. Optimalisasi produksi kedelai [Glysine $\max (L)$ Merril] pada kebun kelapa sawit di lahan gambut dengan aplikasi beberapa komposisi pupuk dan pembenahan tanah. J. Agrotek. Trop Vol.1(2) : 11-15

Balai Besar Pengkajian dan Pengembangan Teknologi Pertanian. 2008. Teknologi Budidaya Kelapa Sawit. Badan Penelitian dan Pengembangan Pertanian.

Direktorat Jenderal Perkebunan. 2015. Statistik Perkebunan Indonesia 2014-2016 Kelapa Sawit.

Elfianti, D. 2005. Peran Mikroba Pelarut Fosfat terhadao Pertumbuhan Tanaman. Universitas Sumatera Utara

Harahap. 2012. Fisiologi Tumbuhan BAB IV Pertumbuhan dan Pekembangan. Tersedia Online pada : digilib.unimed.ac.id. Diakses pada bulan Maret 2018.

Hayati, E., Mahmud, T., dan Fazi, R. 2012. Pengaruh Jenis Pupuk Organik dan Varietas terhadap Pertumbuhan dan Hasil Tanaman Cabai. J.Floratek Vol. 7 : 173-181

Indarti, D. 2014. Outlook Komoditi Kelapa Sawit. Pusat Data dan Sistem Informasi Pertanian Sekertariat Jenderal Kementerian Pertanian.

IRD. Anjarsari, S. Rosniawaty, C. Suherman (2015). Rekayasa ekofisiologis tanaman teh belum menghasilkan klon GMB 7 melalui pemberian asam humat dan pupuk hayati konsorsium. Jurnal Kultivasi. Vol 14, No 1 (2015). Departemen Budidaya Pertanian Faperta UNPAD.

Liferdi, L. 2010. Efek pemberian fosfor terhadap pertumbuahn dan status hara pada bibit manggis. J. Hort. Vol.20(1) : 18-26
Manurung, L.P., Hutabarat, S., Kaswarina, S. 2015. Analisis model peremajaan perkebunan kelapa sawit pola plasma di Desa Meranti Kecamatan Pangkalan Kuras Kabupaten Pelalawan Provinsi Riau. Jurnal Sorot. Vol.10 (1) : 99-113

Rosliani, R., Hidayat, A., Asandhi, A. A. 2004. Respons pertumbuhan cabai dan selada terhadap pemberian pupuk kuda dan pupuk hayati. J. Hort. Vol. 14 (4) : 258-268.

Schmidt, F. H dan Ferguson, J. H. A. 1951. Rainfall Types Based On Wet and Dry Period Rations for Indonesia With Western New Guinea. Jakarta: Kementrian Perhbungan Meteorologi dan Geofisika.

Simanungkalit, R.D.M., Suriadikarta, D.A., Saraswati, R., Setyorini, D., Hartatik, W. 2006. Pupuk Organik dan Pupuk Hayati. Balai Besar Litbang Sumber Daya Lahan Pertanian Badan Penelitian dan Pengembangan Pertanian.

Soelaiman, V., Ernawati, A. 2013. Pertumbuhan dan perkembangan cabai keriting (Capsicum annuum l.) secara in vitro pada beberapa konsetrasi BAP dan IAA. Bul.Aghorti Vol. 1 (1) : 62-66

Sudarmi., Nugraheni, R. Rini, S.N.C. 2013. Kajian pupuk NPK terhadap hasil dan analisis usaha tani cabe rawit rama (Capsicum Frutesence). Widyatama. Vol. 22(1) : 71-79

Suswahyono, U. 2011. Petunjuk Praktis Penggunaan Pupuk Organik Secara Efektif dan Efisien. Penebar Swadaya. Jakarta.

Wardhani, S., Purwani, K. I., Anugerahani, W. 2014. Pengaruh aplikasi pupuk hayati terhadap pertumbuhan dan produktivitas tanaman cabai rawit (Capsicum frutescens L.) Varietas Bhaskara di PT Petrokimia Gresik. Jurnal Sains dan Seni Pomits. Vol.2(1) : 1-5

Wasito. 2013. Diversifikasi Pangan Berbasis Pemanfaatan Lahan Sela Perkebunan Kelapa Sawit dengan Tanaman Pangan di Kabupaten Langkat Sumetra Utara.

Widawati, S. 2015. Uji bakteri simbiotik dan nonsimbiotik pelarut Ca vs. P dan efek inokulasi bakteri pada anakan turi (Sesbania grandiflora L. Pers.). Jurnal Biologi Indonesia. Vol. 11(2) : 295-307 